\title{
Forest Vegetation Profile for Springs Preservation in Arjuna Mount, East Java-Indonesia
}

\author{
Matheus Nugroho $^{1}$, Soemarno ${ }^{2}$, Harsuko Riniwati ${ }^{3}$, Aminudin Afandhi ${ }^{4}$ \\ ${ }^{1}$ Environmental Science Doctoral Program, Brawijaya University, Malang, Indonesia \\ ${ }^{2}$ Agriculture and Environmental Science Faculty, Brawijaya University, Malang, Indonesia \\ ${ }^{3}$ Fisheries and Marine Science and Environmental Science Faculty, Brawijaya University, Malang, Indonesia \\ ${ }^{4}$ Agriculture and Environmental Science Faculty, Brawijaya University, Malang, Indonesia
}

Email address:

mtnugroho@gmail.com (M. Nugroho),smno@ub.ac.id (Soemarno), riniwatisepk@gmail.com (H. Riniwati), a.afandhi@gmail.com (A. Afandhi)

\section{To cite this article:}

Matheus Nugroho, Soemarno, Harsuko Riniwati, Aminudin Afandhi. Forest Vegetation Profile for Springs Preservation in Arjuna Mount, East Java-Indonesia. American Journal of Agriculture and Forestry. Vol. 7, No. 6, 2019, pp. 290-296. doi: 10.11648/j.ajaf.20190706.17

Received: September 6, 2019; Accepted: November 5, 2019; Published: November 15, 2019

\begin{abstract}
The research objectives was to determine Arjuna mount forest vegetation profile for preservation of the area around the spring. The method used was descriptive method. While based on the techniques and tools used to research, the author uses the survey method to obtain facts that occur in the research area, namely in the area around the springs of Arjuna mount, Pasuruan, East Java, Indonesia. Data obtained in the field are then processed and analyzed using GIS, ArcView 3.3 and Google Earth programs. The results of the study explain that the condition of the land slope and the land depth of the Arjuna mount forest provide benefits to the growth and development of plant vegetation profiles. Forest revegetation of with several activities including selection of plant species, nurseries, fertilizing, planting and care provide benefits to the growth and development of plant vegetation profiles. The vegetation profile of the Arjuna mount forest plant provides benefits to the preservation of the area around the springs.
\end{abstract}

Keywords: Forest, Vegetation, Profile, Springs

\section{Introduction}

The structure and diversity of tropical vegetation are determined by the discontinuous distribution of several biotic and/ or abiotic factors, which act in different spatial and temporal scales $[2,5,16]$. At a local or regional scale, plant diversity may be influenced by abiotic conditions, but it may also depend on other ecosystem processes, such as biotic interactions and limitations to seed dispersal $[6,16]$. Vegetation profile growth used to be characterized by a description of the state and characteristic of changes resulting from growth over time. As the definition of word "growing" we can imagine the quantitative enlarging of volume of biomass of living organisms. The descriptions of state and characteristic changes coming up during forest vegetation development are made by use of enumeration survey values. Basic values of enumeration survey are e.g. number of trees per square unit (this is a basic value for computation of mean spacing), mean thickness, mean height, circular base, stock, growth figure [18].

Forest plant vegetation can, however, potentially provide plants and habitats for many birds that utilize naturally occurring woodland habitats [3]. Although stands of native tree species support more local biodiversity than do monocultures of exotic conifers, in some cases exotic conifer plantations can support bird communities as diverse as those in native tree stands [1]. Direct comparisons between plantations and more natural woodlands are useful in identifying woodland features that contribute to bird diversity. As management is one way to influence the utility of plantations to birds, such comparative studies may reveal ways in which plantations can be improved to enhance their value to birds $[4,11,13]$.

Forest revegetation was the restoration of productivity, but not all native species of plants and animals exist. For ecological and economic interests, the new forest could consist of non-native species. Plant cover or vegetation has an important role, that was, as a function of the hydrological 
system, especially the effect of sponges was that it could hold rainwater and regulate its drainage, thereby reducing erosion, flooding and maintaining water flow in the dry season. The hydrological function of the forest will be lost, when vegetation in the higher watersheds was damaged [10].

The general description of Indonesia's forest ecosystems had been damaged since 1950, and the forest continues to increase in damage after the issuance of the foreign capital companies and domestic capital company Law in the 1970s, where the era of forest exploitation began as a source of national development foreign exchange. Damage to forest resources was increasingly out of control when illegal logging, over cutting, encroachment of forest land for agriculture and forest fires occur. Damage to forest resources was increasingly exacerbated when entering the current era of reform and regional autonomy [15]. The results of USAID's monitoring over the past 20 years indicate that there has been a rate of forest destruction in Arjuna mount, some sub-watershed areas have decreased spring discharge, this was allegedly related to forest destruction in the recharge area continues to increase. The number of dry or dead springs was 30 springs, of a total of 41 springs. The main cause of dry springs was damage to protected forests and production in Arjuna mount. Thousands of hectares of Arjuna mount forest were critical, due to fire and illegal logging. The forest area of Arjuna mount in East Java, Indonesia area reaches 12,000 hectares. About 1,500 hectares of them were damaged by fires in 2012 . of the 1,500 hectares burned, only 300 hectares have been rehabilitated.

Based on some of the facts and problems mentioned above, so that was needed a study of Arjuna mount forest vegetation profile for preservation of the area around the spring, as a standard reference in sustainable forest development.

\section{Methods}

The method used was descriptive method. While based on the techniques and tools used to research, the author uses the survey method to obtain facts that occur in the research area, namely in the area around the spring of the Arjuna mount forest. Data obtained in the field are then processed and analyzed using GIS, ArcView 3.3 and Google Earth programs. Data obtained from respondents with questionnaires and analyzed using SEM (structural equation modeling), to find out a general description of respondents' responses about Arjuna mount forest vegetation profile for preservation of the area around the springs.

\section{Results}

\subsection{Vegetation Stratification}

The profile of the vegetation stratification in the Arjuna mount forest includes: (1) the height of trees planted around the spring after 3 years reaching a range of 20-25 meters; (2) canopy of canopy trees interlocked, so that forest trees become green and shady; (3) the height of trees planted around the spring area of Lajer, Dawuan, Watupereng and Sumberkuning was also in the range of 4-20 meters; (4) there were many shrubs and shrubs in the lower part of the tree which were in the range of 1-4 meters; (5) most of the soil around the source area of the spring is covered with cover crops such as grass and other thickets.

The perception of 210 respondents to the Arjuna mount forest stratification profile towards the springs preservation of Lajer, Dawuan, Sumberkuning and Watupereng, in Figure 1. explains that $20.9 \%$ of respondents stated strongly agree, $37.2 \%$ of respondents agreed, 23. 4\% of respondents expressed doubt, $15.2 \%$ of respondents said they did not agree and $3.3 \%$ of respondents stated strongly disagree. Based on these data, the vegetation profile of the Arjuna mount forest stratification influences the springs preservation of in Lajer, Dawuan, Sumberkuning and Watupereng, because almost $58.1 \%$ of respondents agreed and strongly agreed. Figure 1. explains the responses of respondents about the vegetation stratification profile of the Arjuna mount forest.

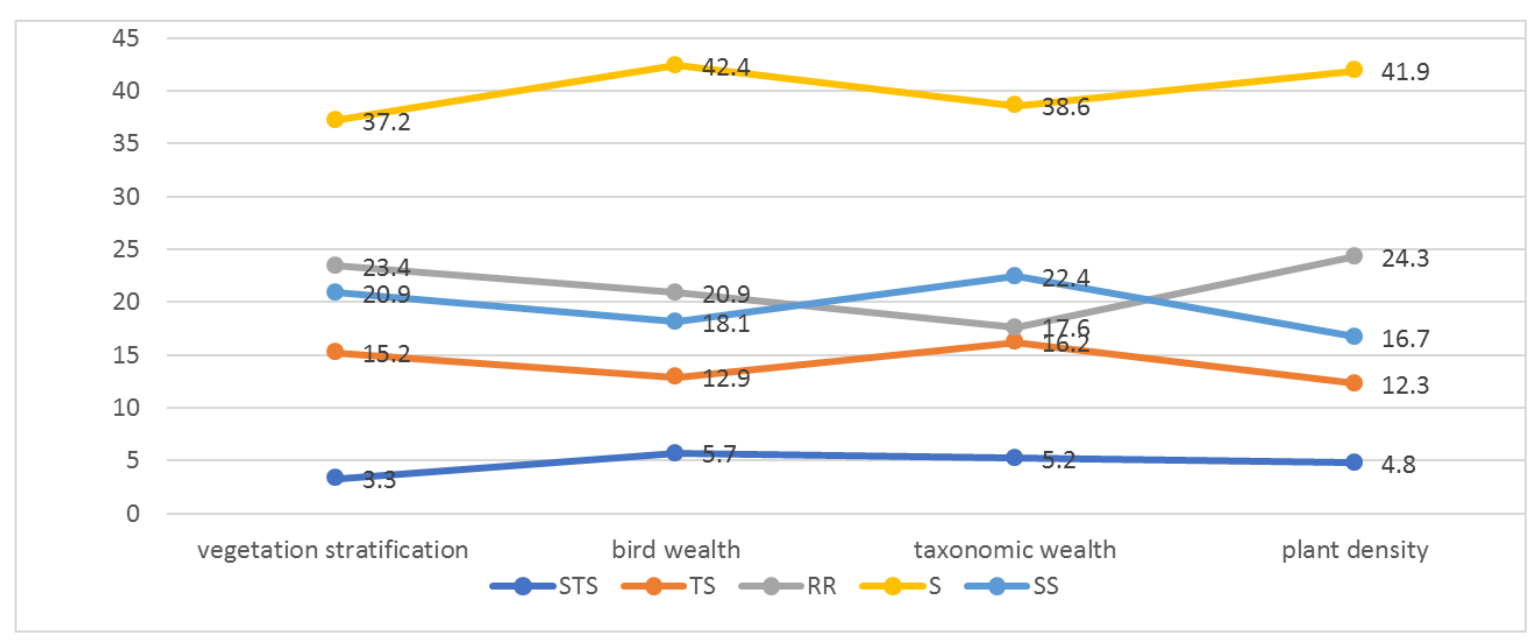

Note: STS: strongly disagree;TS: disagree;RR: doubtful; S: agree;SS: strongly agree

Figure 1. Respondents' perceptions of plant vegetation profile. 


\subsection{Bird Wealth}

The profile of the Arjuna mount forest birds wealth includes: (1) there were regulations for the protection of animal species in the forest area of Arjuna mount; (2) several species of birds, such as finches, greens cucak, parrots, trocok, crabs can still be found in the forest area of Arjuna mount; (3) various birds such as finches, green cucak, parrots, trocok, kepodang could develop on their own in the forest area of Arjuna mount; (4) based on the species protection law that various species of birds such as finches, green cucak, parrots, trocok, ferns are protected from poaching activities; (5) there was the application of social sanctions for community members who hunt birds in the forest.

Perception of 210 respondents to the bird wealth profile in the Arjuna mountain forest area, in Figure 1. shows that $18.1 \%$ of respondents stated strongly agree, $42.4 \%$ of respondents agreed, $20.9 \%$ of respondents expressed doubt, $12.9 \%$ of respondents expressed disagreement and $5.7 \%$ of respondents stated strongly disagree. Based on these data, the bird wealth profile of the Arjuna mount forest area illustrates the preservation of the springs of the springs of Lajer, Dawuan, Sumberkuning and Watupereng, because almost $60.5 \%$ of the respondents agreed and strongly agreed. Figure 1. explains the respondent's response to the profile of Arjuna's mount forest bird wealth.

\subsection{Taxonomy Wealth}

The taxonomic wealth profile of the Arjuna mount forest includes: (1) tree planting in the spring area; (2) planting various types of trees, endemic plants, springs and fruit plants; (3) plant maintenance by forest farmers; (4) increasing forest biodiversity; (5) caring for forest biodiversity.

Perception of 210 respondents to the forest taxonomy profile of Arjuna mount, in Figure 1. shows that $22.4 \%$ of respondents agreed strongly agree, $38.6 \%$ of respondents agreed, $17.6 \%$ of respondents expressed doubt, $16.2 \%$ of respondents expressed disagreement and $5.2 \%$ of respondents stated strongly disagree. Based on these data stated the taxonomic wealth profile of the Arjuna mount forest illustrates the springs vegetation preservation in Lajer, Dawuan, Sumberkuning and Watupereng, this was evidenced by the perception of respondents of $61 \%$ agreeing and strongly agree. Figure 1 . explains the respondent's response to the taxonomic profile of the Arjuna mount forest.

\subsection{Plant Density}

The density profile of the Arjuna mount forest plant includes: (1) the distance of the dense and lush plants; (2) the density of plants increases, between trees more and more branches and leaves; (3) plant density was maintained and not damaged; (4) the number of tree stands was very large; (4) plant density can prevent erosion or landslides in the rainy season.

The perception of 210 respondents towards the Arjuna mount forest plant density profile, in Figure 1. shows that $16.7 \%$ of respondents strongly agreed, $41.9 \%$ of respondents agreed, $24.3 \%$ of respondents expressed doubt, $12.3 \%$ of respondents stated disagree and $4.8 \%$ of respondents stated strongly disagree. Based on these data the density profile of the Arjuna mount forest plant illustrates the preservation of the vegetation of the spring springs of Lajer, Dawuan, Sumberkuning and Watupereng, because almost $58.6 \%$ of respondents said they agreed and strongly agreed. Figure 1. explains the respondent's response to the Arjuna mount forest density profile.

\subsection{Structural Model Forest Vegetation Profile for Springs Preservation}

Based on the results of the structural equation modeling analysis in Figure 2. obtained some significant relationships between exogenous and endogenous variables are as follows:

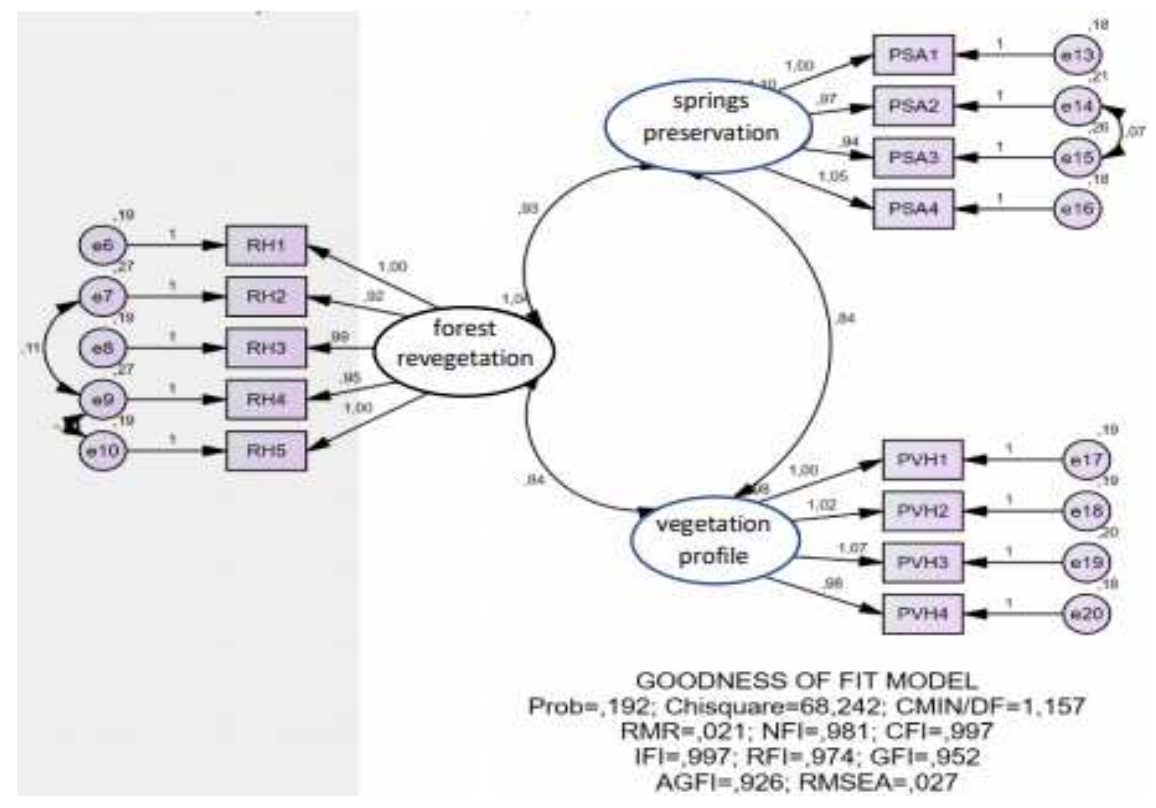

Figure 2. Model of Arjuna mount forest vegetation profile for springs preservation. 
Table 1. Test result of significance regression weights.

\begin{tabular}{|c|c|c|c|c|c|c|c|}
\hline & & & Estimate & S. E. & C. R. & $\mathbf{P}$ & Label \\
\hline forest vegetation profile & $<---$ & forest revegetation & 0.312 & 0.101 & 3.084 & 0.002 & par_18 \\
\hline forest vegetation profile & $<---$ & geography \& land & 0.75 & 0.141 & 5.299 & $* * *$ & par_20 \\
\hline springs preservation & $<---$ & forest revegetation & 0.503 & 0.087 & 5.76 & $* * *$ & par_17 \\
\hline springs preservation & $<---$ & $\begin{array}{l}\text { forest vegetation } \\
\text { profile }\end{array}$ & 0.241 & 0.083 & 2.914 & 0.004 & par_21 \\
\hline
\end{tabular}

The relationship of the influence of forest vegetation profile variables on the preservation of spring water sources was very significant (0.004) with a positive CR of 2.914, Table 1. Because the $\mathrm{p}$ value obtained $>0.05$ and the $\mathrm{CR}$ was positive and $>1.96$ it could be concluded that the forest vegetation profile has a positive and significant effect on the springs preservation. The better the profile of forest vegetation, the preservation of springs will be better, and vice versa. Vegetation profile components such as canopy, litter /humus and root system, play an important role in maintaining the water system, namely in terms of: (1) evaporating water (transpiration); (2) absorbing water into the ground; (3) reducing the kinetic power of raindrops; (4) increase the capacity of the land; (5) to store water in the soil; (6) reducing runoff and (7) reducing soil erosion [20].

\section{Discussion}

\subsection{Vegetation Stratification}

Some of the obstacles faced in the stratification of tree vegetation in Arjuna mount forest were that the growth of tall trees was not the same, so stratification or coating of tree canopy had not been formed. Stratification formed from canopy arrangements of trees can become forest vegetation for water absorption. In forest ecosystems, stratification was formed from the canopy arrangement of several plants, in the form of a vertical direction, this condition occurs because of the composition of dominant, codominant, intermediate, depressed, and lower tree class plants [9].

Some of the successes of tree stratification improvements that have been done carried out for the Arjuna mountain forest revegetation were carrying out planting with the same type and height of trees, and replacing dead plants with new plants whose height was the same as plants that have grown long. In 2014 revegetation in the area of Lajer's spring area of 10 hectares, 700 trees had been added to replace dead plants. The percentage of live plants after 3 years of monitoring was $94 \%$, meaning that from 3000 trees planted in 2014, in the third year of monitoring, there were 2016 plants that lived as many as 2873 trees.

In 2015 revegetation in the Dawuan springs area of 5 hectares, 205 trees were added as a replacement for dead plants. The percentage of live plants after 3 years of monitoring was $92 \%$, meaning that out of 1500 trees planted in 2015 , in the third year of monitoring, there were 1380 trees that live.

In 2016 revegetation in the Sumberkuning springs area of 25 hectares, there were no additional plants for 3 years of monitoring and maintenance. The percentage of live plants after 3 years of monitoring was $86 \%$, meaning that of the 5000 trees planted in 2016, in the third year of monitoring, 2018 plants lived as many as 4485 trees.

In 2017 and 2018 revegetation in the 53 hectares Watupereng spring area, there were no additional plants for 3 years of monitoring and maintenance. The percentage of live plants after 3 years of monitoring was $99 \%$, meaning that from 8000 trees planted at the beginning of the planting year, in the first year of monitoring, that was December 2018, 7958 trees live.

Based on the survey results and socialization in the group discussion, the objectives to be carried out with the maintenance and improvement of plant stratification for revegetation of the Arjuna mountain forest for the second period of 2019-2020 were tree planting according to the height of the plant location, requirements for plant species, minimum plant height, plant species endemic and spring water plant species.

\subsection{Bird Wealth}

Some of the obstacles faced in the bird wealth preservation of the Arjuna mount forest area were the occurrence of poaching, and forest fires in every dry season in the area around the source of water, this causes the number of bird species such as finches, green cucak, parrots, trocok and many pigeons reduced and difficult to obtain. Healthy forest was a conservation area to preserve various species of birds. Forests were a source of various types of natural foods for all types of animals including the types of fruit-eating birds. Revegetation of fruit trees also supports the provision of food sources for various types of fruit-eating birds; therefore the occurrence of forest fires will have an impact on the preservation of biodiversity [8].

Some of the successes in improving the sustainability of bird wealth in the Arjuna mount forest area were (1) planting fruit trees, as a food source for various fruit-eating birds; (2) carry out plant maintenance to maintain the preservation of biodiversity. There were mutually beneficial relationships and interactions between birds and plants. Diaspora of plants will be spread far from its parent plants, because of the help of birds in its spread. Plant seeds will also germinate faster because the skin and flesh of the fruit have been destroyed when passing through the digestion of birds. Birds also benefit from these interactions especially for fruit-eating or nectar birds that use plant parts as food sources [14]. Based on the results of the survey and outreach in group discussions, the objectives to be implemented to improve the sustainability of bird wealth in the Arjuna mountain area in the second period of 2019-2020 were (1) planting fruit trees, 
as a food source for various fruit-eating birds. The types of fruit trees planted include avocados (Persea americana) with 1500 trees; oranges (Citrus sp) number of 1000 trees; coffee (Coffea sp) with 1000 trees; soursop (Annona muricata) with
1500 trees; durian (Durio sp) with 1000 trees and guava (Psidium guajava) with 1000 trees. (2) releasing various types of fruit-eating birds in the revegetation area of Arjuna mount forest.

\subsection{Taxonomy Wealth}

Table 2. Tree planting of the Arjuna mount forest for the 2014-2018 period.

\begin{tabular}{lllll}
\hline NO & Year & Revegetation location & Number of trees & Area (hectare) \\
\hline 1 & 2014 & Lajer - Arjuna mount & 3000 & 10 \\
2 & 2015 & Dawuan - Arjuna mount & 1500 & 5 \\
3 & 2016 & Sumberkuning - Arjuna mount & 5000 & 25 \\
4 & 2017 & Watupereng - Arjuna mount & 6000 & 34 \\
5 & 2018 & Watupereng - Arjuna mount & 4000 & 19 \\
Total & & & 19500 & 93 \\
\hline
\end{tabular}

Source: [17]

Some of the obstacles faced in the preservation of the taxonomic wealth of the Arjuna mount forest were (1) the change in the function of protected forests into production forests and tourist destinations, low plant biodiversity production forests; (2) forest fires in the dry season, plant pests and diseases, and damage to plants by animals and humans reducing biodiversity; (3) the types of plants planted were not in accordance with the ecosystem of forest heights. The higher the level of taxon wealth or forest biodiversity, the higher the level of health and sustainability of the forest, because the higher the biodiversity the more complex the ecological processes that occur so that the level of stability was high [12]. The analysis of species biodiversity measurement requires two indicator data, namely (1) data on the number of species richness and (2) density or abundance [7].

Some of the successes in improving the sustainability of the wealth of the taxon of the Arjuna mount forest were the planting of various species of trees, from endemic species of plants, springs and fruits. The total number of plants was 19500 trees, with an area of revegetation of 93 hectares, in the area around the springs of Lajer, Dawuan, Sumberkuning and Watupereng, which were carried out for 5 years as explained in Table 1.

Planting 3000 trees in the Lajer springs area, with plants including 1000 bamboo (Dendrocalamus asper), 600 candlenuts (Aleurites moluccana), 400 kluwek (Pangium edule), 300 kluweh (Artocarpus communis), 100 banyans (Ficus benyamina), 500 durian (Durio sp) and 100 elo (Ficus glomerata).

Planting 1500 trees in the Dawuan spring area, with types of plants including petung bamboo (Dendroca-lamus asper) 300 trees, candlenut (Aleurities mollucana) 500 trees, banyan (Ficus benyamina) 50 trees, bendo (Artocarpus elasticus) 450 and ivory plant 200 trees.

Planting 5000 trees in the Sumber Kuning spring area, with plants including mountain cypress (Casuarina junghuniana) 2000 trees, swirling 300 trees, petung bamboo (Dendrocalamus asper) 500 trees, cap (Mallocus moluccana) 200 trees, mlandingan (Leucaena glauca) ) 500 trees, kaliandra (Calliandra calothyrsus) 1000 trees and gmelina
(Gmelina arbora) 500 trees.

Planting 8000 trees in the Watu Pereng spring area, with plant species including petung bamboo (Dendrocalamus asper) 1300 trees, banyan (Ficus sp) 500 trees, kluweh (Artocarpus communis) 180 trees, candlenuts (Aleurities mollucana) 450 trees, matoa (Pometia pinnata) 820 trees, cloves (Syzygium aromaticum) 850 trees, soursop (Annona muricata) 800 trees, avocado (Persea americana) 1000 trees, durian (Durio sp) 1200 trees and coffee (Coffea sp) 900 trees.

Based on the survey results and socialization in group discussions, the target to be carried out to improve the preservation of the taxon wealth of Arjuna mount forest in the second period of 2019-2020 was the planting of 18,000 trees in the area of Curahtangkil springs-Dayurejo, Puthukbunder-Jatiarjo and Talangwatu-Leduk. Some tree species planted include: (1) endemic plant species, namely: bendo (Artocarpus elasticus) 1000 trees, kluwek (Pangium edule) 1000 trees, breadfruit (Artocarpus altilis) 1000 trees, candlenut (Aleurites mollucanus) 1000 trees, gondang (Pangium edule) 1000 trees, breadfruit (Artocarpus altilis) 1000 trees, candlenut (Aleurites mollucanus) 1000 trees, gondang (Ficus variegate) 1000 trees; (2) springs plant species, namely: petung bamboo (Dendrocalamus sp) 2000 trees, sugar palm (Arenga pinnata) 1000 trees, banyan (Ficus benyamina) 2000 trees, epek (Ficus elastica) 1000 trees; (3) fruit plant species, namely: avocado (Persea americana) 1500 trees, oranges (Citrus sp) 1000 trees, coffee (Coffea sp) 1000 trees, soursop (Annona muricata) 1500 trees, durian (Durio sp) 1000 trees and guava (Psidium guajava) 1000 trees. One biological component in the forest was a plant. If biodiversity refers to all living things in the forest, the diversity of trees was all types of trees that were in the forest. Natural forests tend to naturally have various types of plants. Biodiversity was used in the assessment of forest health indicators caused by three things: (1) sensitive to change; (2) ecological system indicators; and (3) spatial, temporal and trophic heterogeneity. In the assessment of forest health, parameters that could be used for biodiversity indicators were the index of diversity, the index of similarity, the index of diversity, and the index of species evenness [19]. 


\subsection{Plant Density}

Some of the obstacles faced in the Arjuna mount forest plants density was the height of the initial plant of 1.5 meters, and the size of the width and distance between plants was 10 meters x 10 meters (200 trees/ha). The results of verification after 3 years of plant maintenance showed that tree stands were rare, plant canopy density was less than $40 \%$ of canopy closure. The size of plant canopy density was divided into 3 canopy density classes, namely: (1) meeting stands, if there were more than $70 \%$ canopy closure; (2) enough stands, if there are $40-70 \%$ crown cover and (3) rare stands, if there was less than $40 \%$ canopy cover [9].

Some of the successes in improving the density of Arjuna mount forest plants were (1) replacing damaged and dead plants with new plants with the same tree height, for 3 years of maintenance; (2) doing maintenance includes cleaning plants from grass, weeding plants, making firebreaks during the dry season, preventing plant diseases, fertilizing and administering drugs, weeding from weeds, giving water during the dry season and protecting plants from natural and human damage. Conduct joint monitoring, directly at the planting location every 4 months, and make a report as a basis for corrective and preventive actions.

Plant density was a value that shows the number of species of plants in each unit area. Plant density was related to competition between plants in getting sunlight and nutrients. Optimal plant density was closely related to plant growth in need of water, nutrients, and oxygen that was absorbed mainly by the roots and radiation and $\mathrm{CO}_{2}$ absorbed by the leaves under sufficient conditions. Lack of water, nutrients, and light radiation causes plant growth to be hampered so that plant density was not optimal. Based on the survey results and socialization in the group discussion, the targets to be carried out to improve the Arjuna mount forest plants density in the second period of 2019-2020 were (1) preparation of healthy plant seeds; (2) seedlings of various species (endemic plants, springs and fruits); (3) uniform plant height; (4) sufficient nutrient content for plants; (5) availability of water for plants during the dry season; (6) treatment of plants from pest and weed disorders; (7) fertilizer application; (8) sufficient sunlight for plants.

\section{Conclusion}

The condition of the land slope and the land depth of the Arjuna mount forest provides benefits to the growth and development of plant vegetation profiles. Forest revegetation of with several activities including selection of plant species, nurseries, fertilizing, planting and care provide benefits to the growth and development of plant vegetation profiles. The vegetation profile of the Arjuna mount forest plant provides benefits to the preservation of the area around the springs.

Plant vegetation stratification, namely the height of the tree 20-25 meters, the canopy of the canopy interlocked, the height of the tree around the spring area of 4-20 meters, the lower part of the tree many shrubs and shrubs, the soil around the spring area was covered with plants such as grass and other shrubs provide benefits to the preservation of the area around the spring. The richness of Arjuna mount forest birds, namely several species of birds, such as finches, green cucaks, parrots, trocok, and dumplings, still exist in the forest area of Arjuna mount, showing that the preservation of the area around the spring was well maintained. The taxonomic richness of Arjuna mount forests, which was planting trees in the water source area, planting various types of trees, endemic plants, spring plants and fruit plants, caring for plants, increasing forest biodiversity and caring for forest biodiversity, provides benefits to the preservation of areas in around the spring. Arjuna mount forest plant density was the distance of dense and lush plants, plant density increases, between trees more branches and leaves, plant density was not damaged, the number of tree stands was very large, plant density can prevent erosion in the rainy season, can provide benefits to the preservation of the area around the spring.

\section{References}

[1] Archaux, F. and Bakkaus, N. 2007. Relative impact of stand structure, tree composition and climate on mountain bird communities. Forest Ecology and Management 247: 72-79.

[2] Arruda, D. M, Schaefer C. E. G. R, and Correa G. R., 2015 Landforms and soil attributes determine the vegetation structure in the Brazilian semiarid. Folia Geobot 50: 17584.

[3] Brockerhoff, E., Jactel, H., Parrotta, J., Quine, C. and Sayer, J. 2008. Plantation forests and biodiversity: oxymoron or opportunity? Biodiversity and Conservation 17: 925-951.

[4] Calladine, J., Humphreys, E. M., Strachan, F. and Jardine, D. C. 2009. Forestry thinning in commercial conifer plantations has little effect on bird species richness and breeding abundance. Bird Study 56: 137-141.

[5] Dale, M. R. T., 1999. Spatial Pattern Analysis in Plant Ecology. Cambridge, UK: Cambridge University Press.

[6] Dalling J. W., Muller-Landau H. C, Wright S. J, et al., 2002. Role of dispersal in the recruitment limitation of neotropical pioneer species. J Ecol 90: 714-27.

[7] Gaston, K. J. and J. I. Spicer, 1998. Biodiversity: an introduction. Blackwell science. Oxford; Malden. Ma. USA

[8] Indrawan, M, Primack, R.B, Supriatna J., 2007. Biology conservation. Obor foundation Indonesia, Jakarta

[9] Indriyanto, 2006. Forest ecology. Jakarta: Bumi aksara publisher.

[10] Jhon, MacKinnon, Child G. and J. Thorsell, 1993. Management of protected areas in the tropics. Gadjah Mada University Press. Yogyakarta.

[11] Lantschner, M., Rusch, V. and Peyrou, C., 2008. Bird assemblages in pine plantations replacing native ecosystems in NW Patagonia. Biological Conservation 17: 969-989.

[12] Leksono, A. S., 2011. Biodiversity: theory and application. Brawijaya University Press. UB Press. 
[13] Luck, G. W. and Korodaj, T. N., 2008. Stand and landscapelevel factors related to bird assemblages in exotic pine plantations: implications for forest management. Forest Ecology and Management 255: 2688-2697.

[14] Mardiastuti, A., Salim, L.R, Mulyani Y.A., 2001. Sulawesi hornbill eating behavior on two types of Ficus in Lambusango wildlife reserve, Buton. Conservation media. 6 (1): 7-10.

[15] Oldeman, L. R., 1992. The Global Extent of Soil Degradation. In Greenland, D. J. and Szobolcs, I. (Ed). Soil Resilience and Sustainable Land Use. CAB International. $561 \mathrm{pp}$.

[16] Peña-Claros, M, Poorter L, Alarcón A, et al., 2012. Soil effects on forest structure and diversity in a moist and a dry tropical forest. Biotropica 44: 276-83.
[17] PT. Sorini Agro Asia Corporindo, 2017. Forest rehabilitation program for Arjuna mount, Prigen Pasuruan, East Java. Indonesia.

[18] Rybansky, M., Brenova, M., Cermak, J., Van Genderen J. and Å. Sivertun, 2016. Vegetation structure determination using LIDAR data and the forest growth parameters. 8th IGRSM International Conference and Exhibition on Remote Sensing and GIS (IGRSM 2016). IOP Conf. Series: Earth and Environmental Science 37 (2016) 012031.

[19] Safei, R. S. and M. K. Tsani, 2016. Forest health. Forest health assessment using forest health monitoring techniques. Plantaxia. Yogyakarta.

[20] Soerianegara, I. and Indrawan, 1978. Indonesian forest ecology. Faculty IPB. Bogor. 